\title{
Tub Dosing Unit
}

National Cancer Institute

\section{Source}

National Cancer Institute. Tub Dosing Unit. NCI Thesaurus. Code C78784.

A dosing unit equal to the amount of active ing redient(s) contained in a flat-bottomed container which is typically round and wider than deep. 